\title{
Llano Grande Lake Bottom Sediments-A Chronicle of Water-Quality Changes in the Arroyo Colorado, South Texas, 1989-2001
}

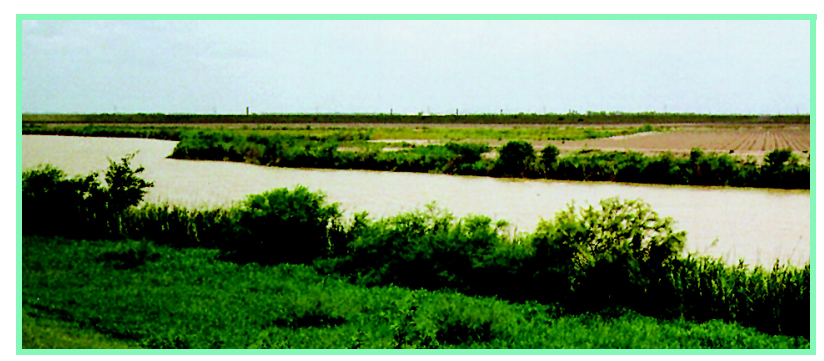

Llano Grande Lake and nearby agriculture (photograph by Roger M. Miranda, Texas Natural Resource Conservation Commission).
The Arroyo Colorado, an ancient channel of the Rio Grande, extends 90 miles from Mission, Tex., to the Laguna Madre. The Arroyo Colorado flows through areas of intense agricultural cultivation and through important habitat for migrating birds and other wildlife, including several wildlife sanctuaries and refuges. The above-tidal segment of the Arroyo Colorado is included in the State of Texas 2000 Clean Water Act 303(d) ${ }^{1}$ list in part because of elevated concentrations of the hydrophobic legacy pollutants DDE (a DDT breakdown product), chlordane, and toxaphene in fish tissue. This report addresses three questions:

- Do legacy pollutants (organochlorine compounds, major and trace elements) occur in the Arroyo Colorado at present and at what concentrations?

- How has the occurrence of selected legacy pollutants in the Arroyo Colorado changed over time?

\section{- Are current concentrations of legacy pollutants in bottom sediments at levels of concern} for the health of aquatic biota?

To answer these questions, the U.S. Geological Survey (USGS), in cooperation with the U.S. Environmental Protection Agency (USEPA), collected and analyzed a sediment core from Llano Grande Lake on the Arroyo Colorado (fig. 1). Sediment cores can be used to reconstruct historical trends in concentrations of hydrophobic contaminants (Eisenreich and others, 1989; Van Metre and others, 1997, 2000). The lake is part of the Rio Grande delta drainage system (fig. 1). The lake is 6 miles long and has a maximum width of 600 feet.

\section{Highlights of Findings}

- Concentrations of chlordane and toxaphene are below minimum reporting levels in sediments deposited since 1989.

- Concentrations of DDE have decreased since 1989 but remain at levels that might present a threat to the health of aquatic biota.

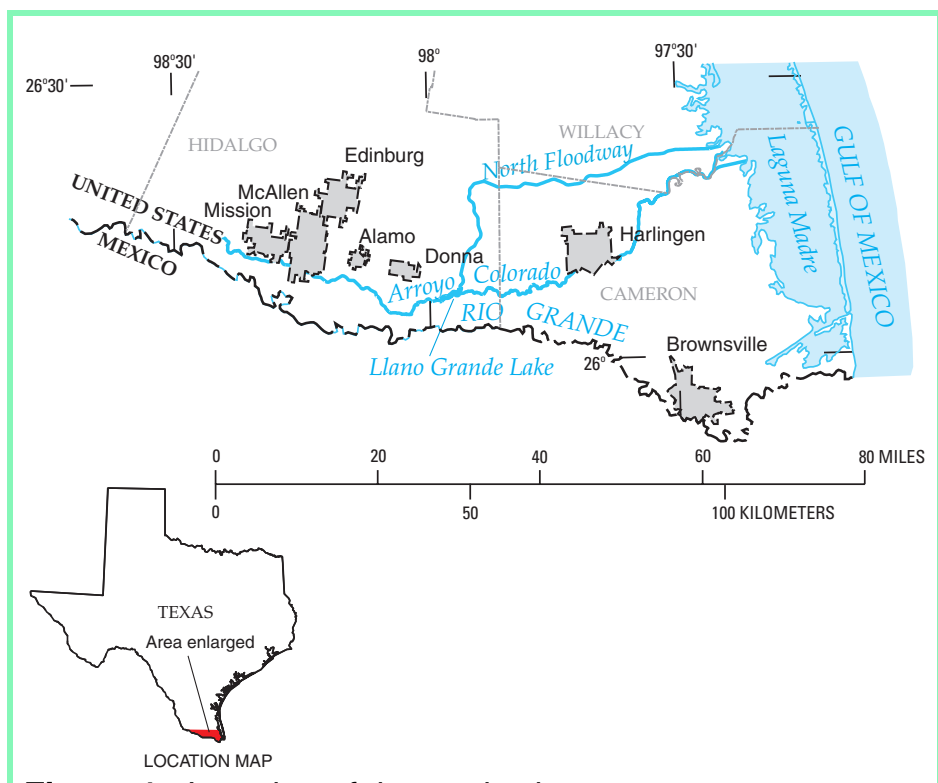

Figure 1. Location of the study site.

${ }^{1}$ The State of Texas Clean Water Act 303(d) list comprises surface-water bodies in Texas identified by the Texas Natural Resource Conservation Commission as impaired (do not meet applicable water-quality standards) or threatened (are not expected to meet applicable standards in the near future). Section 303(d) of the Federal Clean Water Act (together with related regulations) requires each State to assess the quality of its surface waters and to develop waterquality improvement strategies for impaired and threatened waters. 


\section{Collection and Age-Dating of the Sediment Core}

To find as thick a sequence of undisturbed sediments as possible, the sediment core was collected from a protected arm of Llano Grande Lake, where scouring of sediment was assumed not to occur except in the case of very large floods. A 114-centimeter (cm)-long push core was obtained by pushing a plastic cylinder directly into the mud. The sediment was fairly homogeneous, with light brownishgray clay throughout the length of the core and some fine sand between the $80-$ and $90-\mathrm{cm}$ depth.

The core was subsampled by pushing the sediment up through the plastic liner and slicing 4- to 6-cm-thick layers of sediment off the top (see photo below). Each sample was analyzed for cesium-137 $\left({ }^{137} \mathrm{Cs}\right)$, organochlorine compounds, major and trace elements, and organic carbon at the USGS National Water Quality Laboratory in Denver, Colo., using the published USGS methods cited: ${ }^{137} \mathrm{Cs}$ was measured by radioactive counting (Van Metre and others, 1998); organochlorine compounds were measured by dual capillary-column gas chromatography with electron capture detection (GC-ECD) (Foreman and others, 1995); major and trace elements were measured by inductivelycoupled plasma/mass spectrometry (ICP/MS) (Arbogast, 1996); and organic carbon was measured by combustion (Arbogast, 1996). Grain size was not measured, but (unpublished) data from other coring studies by the authors indicate that it is typically in the silt- and clay-size range.

The sediment core was age-dated on the basis of the ${ }^{137} \mathrm{Cs}$ profile and records of historical flooding in the Arroyo Colorado. A byproduct of nuclear weapons testing, ${ }^{137} \mathrm{Cs}$ is a radioactive isotope with a half-life of 30.1 years. Concentrations reached their peak in the atmosphere in 1963 and have been decreasing exponentially ever since. Thus an undisturbed sequence of sediments whose lowest parts predate 1963 should contain a ${ }^{137} \mathrm{Cs}$ peak and then an exponential decrease toward the top of the core. The ${ }^{137} \mathrm{Cs}$ pattern in the Llano Grande Lake core is very erratic in the lower part of the core and then decreases smoothly from $62 \mathrm{~cm}$ to the top of the core (fig. 2). This pattern suggests that the top $62 \mathrm{~cm}$ of sediment is an undisturbed sequence, that is, it post-dates any flooding events that could have caused scouring and redeposition of sediments. The last major flood in the Arroyo Colorado occurred in September 1988 when the maximum flow measured 2.4 channel miles upstream from the branching of the Arroyo Colorado and the North Floodway was 11,400 cubic feet per second (International Boundary and Water Commission, 1988). Therefore a depth of $62 \mathrm{~cm}$ in the core was assigned a date of 1989 , and a constant mass accumulation rate was assumed from 1989 to present. It is not known when the sediments from $62 \mathrm{~cm}$ to the bottom

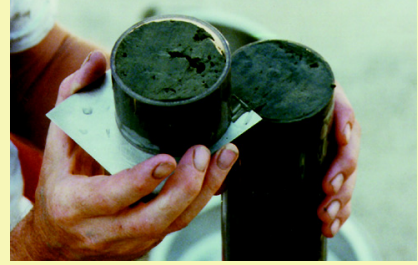

Slicing a subsample from a core for laboratory analysis.

\section{Trends in Organochlorine Compounds}

Of the 15 organochlorine compounds for which the sediment core was analyzed, only dieldrin, DDT, DDE, and polychlorinated biphenyls (PCBs) occurred at concentrations above their minimum reporting levels. Gamma$\mathrm{HCH}$ (lindane), heptachlor, aldrin, heptachlor epoxide, endosulfan, DDD (another breakdown product of DDT), and mirex were not detected in any of the core samples at a minimum reporting level of 1.0 microgram per kilogram $(\mu \mathrm{g} / \mathrm{kg}$ ) (top core sample) and $0.5 \mu \mathrm{g} / \mathrm{kg}$ (all other samples). Methoxychlor was not detected at a minimum reporting level of $4.0 \mu \mathrm{g} / \mathrm{kg}$ (top core sample) and $2.0 \mu \mathrm{g} / \mathrm{kg}$ (all other samples). Chlordane and toxaphene, two of the legacy pollutants for which the Arroyo Colorado was placed on the 303(d) list, were not detected in any of the core samples at minimum reporting levels of 10 and $100 \mu \mathrm{g} / \mathrm{kg}$, respectively (top core sample), and 5 and $50 \mu \mathrm{g} / \mathrm{kg}$, respectively (all other samples).

Most of the total DDT (equal to the sum of DDT, DDE, and DDD) occurs in the form of DDE, the concentrations of which are 50 to 100 times that of parent DDT (table 1). In general, concentrations of total DDT decrease in the part of the core assumed to represent undisturbed sedimentation from a high of $121 \mu \mathrm{g} / \mathrm{kg}$ deposited in the early $1990 \mathrm{~s}$ to $51 \mu \mathrm{g} / \mathrm{kg}$ in the most recently deposited sediments (fig. 2). However, the concentration of DDE in the most recently deposited sediments $(49 \mu \mathrm{g} / \mathrm{kg})$ is about 60 percent higher than the Probable Effect Concentration (PEC), the concentration above which adverse effects on benthic biota are expected to occur; the PEC is a consensus-based sediment quality guideline developed by MacDonald and others (2000). The elevated concentration of DDE in recently deposited sediments indicates that DDE is still present in the Arroyo Colorado at concentrations of environmental concern. The slight increasing trend in total DDT at the top of the core probably is related to any increase in organic carbon content, and thus the trend probably reflects partitioning rather than increased loading.

Concentrations of the two other organochlorine compounds detected in the core, dieldrin and PCBs, were below the Threshold Effect Concentration (TEC) in all cases (table 1). The TEC is the concentration below which
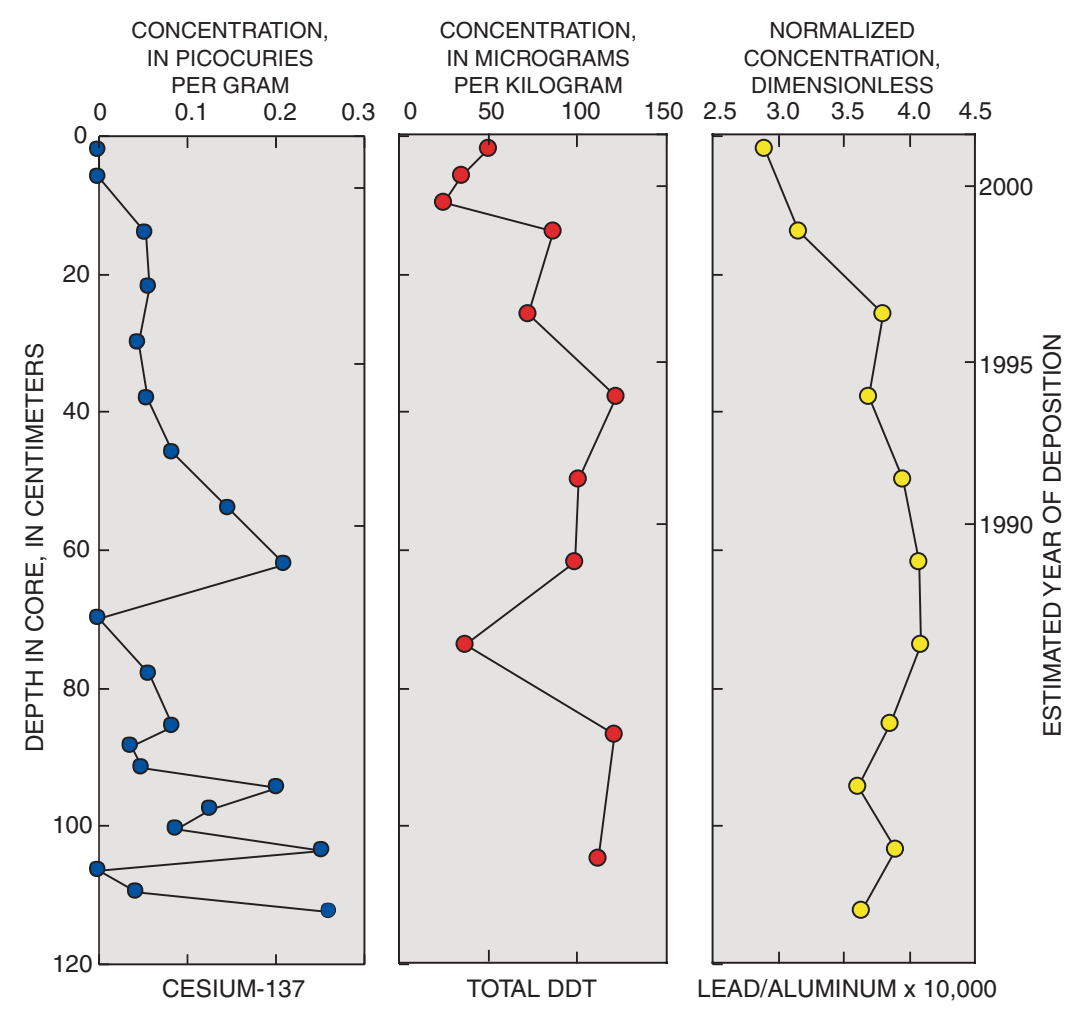

Figure 2. Concentrations of Cesium-137, total DDT, and normalized lead from a sediment core collected from Llano Grande Lake. Sediments from the bottom of the core up to about $62 \mathrm{~cm}$ are assumed to have been disturbed, and no dates were assigned to this interval. 
Table 1. Concentrations of selected organochlorine compounds and major and trace elements in the Llano Grande Lake sediment core

[See text for additional compounds not detected; cm, centimeters; $\mu \mathrm{g} / \mathrm{kg}$, micrograms per kilogram; <, less than; E, estimated; --, unknown or not applicable; TEC, Threshold Effect Concentration (MacDonald and others, 2000); PEC, Probable Effect Concentration (MacDonald and others, 2000); mg/kg, milligrams per kilogram]

\begin{tabular}{|c|c|c|c|c|c|c|c|c|c|c|c|c|}
\hline \multirow[b]{2}{*}{$\begin{array}{c}\text { Core } \\
\text { interval } \\
(\mathbf{c m})\end{array}$} & \multirow[b]{2}{*}{$\begin{array}{c}\text { Estimated } \\
\text { date of } \\
\text { deposition }\end{array}$} & \multicolumn{11}{|c|}{ Organochlorine compounds } \\
\hline & & $\begin{array}{l}\text { Dieldrin } \\
(\mu \mathbf{g} / \mathbf{k g})\end{array}$ & $\begin{array}{c}\text { DDE } \\
(\mu \mathrm{g} / \mathbf{k g})\end{array}$ & $\begin{array}{c}\text { DDD } \\
(\mu \mathrm{g} / \mathrm{kg})\end{array}$ & $\begin{array}{c}\text { DDT } \\
(\mu \mathrm{g} / \mathbf{k g})\end{array}$ & $\begin{array}{c}\text { Total } \\
\text { DDT } \\
(\mu \mathrm{g} / \mathrm{kg})\end{array}$ & $\begin{array}{c}\text { PCB } \\
1242 \\
(\mu \mathrm{g} / \mathrm{kg})\end{array}$ & $\begin{array}{c}\text { PCB } \\
1254 \\
(\mu \mathrm{g} / \mathrm{kg})\end{array}$ & $\begin{array}{c}\text { PCB } \\
1260 \\
(\mu \mathrm{g} / \mathrm{kg})\end{array}$ & $\begin{array}{c}\text { Total } \\
\text { PCB } \\
(\mu \mathrm{g} / \mathrm{kg})\end{array}$ & $\begin{array}{c}\text { Chlor- } \\
\text { dane } \\
(\mu \mathrm{g} / \mathrm{kg})\end{array}$ & $\begin{array}{c}\text { Toxa- } \\
\text { phene } \\
(\mu \mathrm{g} / \mathrm{kg})\end{array}$ \\
\hline $0-4$ & 2001 & 1.0 & 49 & $<1.0$ & 1.5 & 51 & $<10$ & $<10$ & $<10$ & $<30$ & $<10$ & $<100$ \\
\hline $4-8$ & 2001 & E.4 & 34 & $<.5$ & .8 & 35 & $<5.0$ & $<5.0$ & $<5.0$ & $<15$ & $<5$ & $<50$ \\
\hline $8-12$ & 2000 & $<.5$ & 25 & $<.5$ & $<.5$ & 25 & $<5.0$ & $<5.0$ & $<5.0$ & $<15$ & $<5$ & $<50$ \\
\hline $12-16$ & 1999 & E.5 & 90 & $<.8$ & E1.2 & 90 & $<5.0$ & $<5.0$ & $<5.0$ & $<15$ & $<5$ & $<50$ \\
\hline $24-28$ & 1997 & E.2 & 72 & $<.5$ & .9 & 73 & $<5.0$ & $<5.0$ & $<5.0$ & $<15$ & $<5$ & $<50$ \\
\hline $36-40$ & 1994 & .5 & 120 & $<.6$ & 1.4 & 121 & $<5.0$ & $<5.0$ & $<5.0$ & $<15$ & $<5$ & $<50$ \\
\hline $48-52$ & 1992 & E.4 & 100 & $<.6$ & 1.1 & 101 & $<5.0$ & E3.5 & E2.2 & E5.7 & $<5$ & $<50$ \\
\hline $60-64$ & 1989 & E. 3 & 98 & $<.5$ & 1.0 & 99 & $<5.0$ & E4.4 & E2.5 & E6.9 & $<5$ & $<50$ \\
\hline $72-76$ & -- & $<.5$ & 37 & $<.5$ & $<.5$ & 37 & $<5.0$ & $<5.0$ & $<5.0$ & $<15$ & $<5$ & $<50$ \\
\hline $84-90$ & -- & E. 3 & 120 & $<.5$ & 1.0 & 121 & $<5.0$ & E4.7 & E2.6 & E7.3 & $<5$ & $<50$ \\
\hline 102-108 & -- & E.4 & 110 & $<.6$ & 1.3 & 111 & $<5.0$ & E8.1 & E3.3 & E11.4 & $<5$ & $<50$ \\
\hline TEC & -- & 1.9 & 3.2 & 4.9 & 4.2 & 5.3 & -- & -- & -- & 59.8 & 3.24 & -- \\
\hline PEC & -- & 61.8 & 31 & 28.0 & 62.9 & 572 & -- & -- & -- & 676.0 & 17.6 & -- \\
\hline
\end{tabular}

\begin{tabular}{|c|c|c|c|c|c|c|c|c|c|}
\hline \multirow[b]{2}{*}{$\begin{array}{c}\text { Core } \\
\text { interval } \\
(\mathbf{c m})\end{array}$} & \multirow[b]{2}{*}{$\begin{array}{l}\text { Estimated } \\
\text { date of } \\
\text { deposition }\end{array}$} & \multicolumn{8}{|c|}{ Major elements } \\
\hline & & $\begin{array}{c}\text { Aluminum } \\
(\mathrm{mg} / \mathrm{kg})\end{array}$ & $\begin{array}{c}\text { Calcium } \\
(\mathrm{mg} / \mathrm{kg})\end{array}$ & $\begin{array}{c}\text { Iron } \\
(\mathbf{m g} / \mathbf{k g})\end{array}$ & $\begin{array}{l}\text { Potas- } \\
\text { sium } \\
(\mathrm{mg} / \mathrm{kg})\end{array}$ & $\begin{array}{c}\text { Mag- } \\
\text { nesium } \\
\text { (mg/kg) }\end{array}$ & $\begin{array}{l}\text { Sodium } \\
(\mathrm{mg} / \mathrm{kg})\end{array}$ & $\begin{array}{l}\text { Phos- } \\
\text { phorus } \\
\text { (mg/kg) }\end{array}$ & $\begin{array}{r}\text { Titanium } \\
(\mathrm{mg} / \mathrm{kg})\end{array}$ \\
\hline $0-4$ & 2001 & 59,100 & 131,500 & 28,300 & 16,400 & 11,850 & 4,675 & 1,270 & 2,860 \\
\hline $12-16$ & 2001 & 60,200 & 114,000 & 27,300 & 17,400 & 10,800 & 5,880 & 1,200 & 3,030 \\
\hline $24-28$ & 2000 & 58,200 & 121,000 & 27,300 & 16,800 & 10,100 & 5,720 & 1,550 & 2,970 \\
\hline $36-40$ & 1999 & 59,600 & 118,000 & 28,000 & 17,100 & 10,400 & 5,920 & 1,380 & 3,040 \\
\hline $48-52$ & 1997 & 61,300 & 114,000 & 28,700 & 17,700 & 10,600 & 5,800 & 1,240 & 3,160 \\
\hline $60-64$ & 1994 & 62,400 & 114,000 & 29,500 & 17,500 & 11,300 & 5,120 & 1,290 & 3,050 \\
\hline $72-76$ & 1992 & 60,600 & 119,000 & 29,200 & 17,400 & 10,600 & 4,940 & 1,380 & 3,120 \\
\hline $84-87$ & 1989 & 58,000 & 127,000 & 28,100 & 16,400 & 10,200 & 4,550 & 1,320 & 2,920 \\
\hline $93-96$ & -- & 63,000 & 110,000 & 28,400 & 17,300 & 10,600 & 5,220 & 1,010 & 3,140 \\
\hline $102-105$ & -- & 55,267 & 135,333 & 25,600 & 16,067 & 9,813 & 5,443 & 1,163 & 2,840 \\
\hline $111-114$ & -- & 43,100 & 184,000 & 20,600 & 12,200 & 8,620 & 4,980 & 1,060 & 2,210 \\
\hline
\end{tabular}

\begin{tabular}{|c|c|c|c|c|c|c|c|c|c|}
\hline \multirow[b]{2}{*}{$\begin{array}{c}\text { Core } \\
\text { interval } \\
(\mathrm{cm})\end{array}$} & \multirow[b]{2}{*}{$\begin{array}{c}\text { Estimated } \\
\text { date of } \\
\text { deposition }\end{array}$} & \multicolumn{8}{|c|}{ Trace elements } \\
\hline & & $\begin{array}{l}\text { Arsenic } \\
\text { (mg/kg) }\end{array}$ & $\begin{array}{c}\text { Cadmium } \\
\text { (mg/kg) }\end{array}$ & $\begin{array}{l}\text { Chro- } \\
\text { mium } \\
\text { (mg/kg) }\end{array}$ & $\begin{array}{l}\text { Copper } \\
\text { (mg/kg) }\end{array}$ & $\begin{array}{l}\text { Nickel } \\
\text { (mg/kg) }\end{array}$ & $\begin{array}{c}\text { Lead } \\
(\mathrm{mg} / \mathrm{kg})\end{array}$ & $\begin{array}{c}\text { Zinc } \\
(\mathrm{mg} / \mathrm{kg})\end{array}$ & $\begin{array}{c}\text { Organic } \\
\text { carbon } \\
\text { (percent) }\end{array}$ \\
\hline $0-4$ & 2001 & 9.1 & 0.39 & 41 & 21 & 21 & 17 & 93 & 1.3 \\
\hline $12-16$ & 2001 & 9.3 & .39 & 40 & 20 & 21 & 19 & 92 & .79 \\
\hline $24-28$ & 2000 & 8.4 & .42 & 42 & 23 & 21 & 22 & 94 & .83 \\
\hline $36-40$ & 1999 & 8.7 & .43 & 42 & 21 & 21 & 22 & 95 & .90 \\
\hline $48-52$ & 1997 & 9.1 & .44 & 44 & 22 & 21 & 24 & 97 & .86 \\
\hline $60-64$ & 1994 & 9.3 & .46 & 44 & 23 & 22 & 25 & 102 & .89 \\
\hline $72-76$ & 1992 & 9.2 & .46 & 45 & 24 & 22 & 25 & 99 & .86 \\
\hline $84-87$ & 1989 & 10.0 & .43 & 43 & 23 & 21 & 22 & 92 & .93 \\
\hline $93-96$ & -- & 9.7 & .42 & 45 & 21 & 21 & 23 & 95 & .81 \\
\hline $102-105$ & -- & 9.0 & .38 & 40 & 19 & 20 & 22 & 85 & .83 \\
\hline $111-114$ & -- & 7.9 & .29 & 33 & 32 & 18 & 16 & 68 & .90 \\
\hline TEC & -- & 9.8 & .99 & 43.4 & 31.6 & 22.7 & 35.8 & 121 & -- \\
\hline PEC & -- & 33.0 & 4.98 & 111 & 149 & 48.6 & 128 & 459 & -- \\
\hline
\end{tabular}


adverse effects on benthic biota are not expected to occur (MacDonald and others, 2000). This finding indicates that direct exposure to dieldrin and PCBs at this site probably does not pose a threat to the health of aquatic biota. PCBs were not detected in the upper $40 \mathrm{~cm}$ of sediments. Nationwide, concentrations of PCBs in lake and reservoir sediments generally peaked in the mid- to late1960s, then decreased following restrictions on PCB use imposed in 1971 (Van Metre and others, 1997, 1998). The lack of detection of PCBs in the upper part of the Llano Grande core is consistent with the hypothesis that the upper part of the core represents sediments deposited after the 1970s.

\section{Trends in Major and Trace Elements}

Concentrations of major elements (table 1), an indication of the mineralogic origin of the sediment, are fairly constant from a depth of about $93 \mathrm{~cm}$ to the top of the core. From the bottom of the core to about $93 \mathrm{~cm}$, concentrations of aluminum and titanium increase, and concentrations of calcium decrease, suggesting an increase in clay content.

There is no evidence in the core that trace elements in sediments in Llano Grande Lake are likely to cause adverse effects to benthic biota, according to the consensus-based sediment quality guidelines (MacDonald and others, 2000) (table 1). Concentrations of trace elements at the top of the core are below the TEC. Concentrations of most trace elements decrease at the bottom of the core, coincident with decreased clay content as represented by aluminum. This concentration decrease probably is because many trace elements tend to be associated with the clay minerals in sediment.

Trends in lead concentrations are consistent with the assumption of undisturbed deposition of the upper part of the core since 1989. Concentrations of lead, when normalized to aluminum concentrations to account for differences in clay content down the core, decrease from $62 \mathrm{~cm}$ to the top of the core (fig. 2). This is consistent with the decreasing trends in lead in numerous other reservoir cores that were caused by the elimination of lead in gasoline in the 1970s (Callender and Van Metre, 1997). The lack of a sharp lead peak supports the hypothesis that these sediments were deposited after the 1970s.

\section{Conclusions and Implications}

Information on contaminants associated with sediments from the Arroyo Colorado since 1989 can be reconstructed from a sediment core collected from Llano Grande Lake. Major floods that moved and redeposited sediments prevented obtaining an undisturbed sequence of sediments that represents deposition earlier than 1989. Analyses of discrete intervals within the sediment core indicate that two of the legacy pollutants of interest in the Arroyo Colorado, chlordane and toxaphene, are not detectable in sediments deposited at the coring site after 1989. Concentrations of a third legacy pollutant, DDE, have decreased by more than one-half since the early 1990s. Concentrations of DDE in the most recently deposited sediments, however, still exceed concentrations thought to be toxic to benthic biota by a factor of about 1.5. Other organochlorine compounds analyzed occurred at extremely low concentrations (dieldrin), occurred only in older sediments (PCBs), or were not detected.

Trace elements occurred in a range of concentrations at which adverse effects on benthic biota are not expected. Some chromium concentrations only slightly exceed the upper level of this range and were less than one-half the concentration above which adverse effects on benthic biota are expected to occur.

\section{Acknowledgments}

This project was funded by the U.S. Environmental Protection Agency. We thank Sylvia Ritzky and Philip Crocker (USEPA), Jennifer Wilson and Edward Callender (USGS), and Roger Miranda (Texas Natural Resource Conservation Commission) for their helpful comments on the manuscript.

\section{References}

Arbogast, B.F., ed., 1996, Analytical methods manual for the Mineral Resource Surveys Program: U.S. Geological Survey Open-File Report 96-525, 248 p.

Callender, Edward, and Van Metre, P.C., 1997, Reservoir sediment cores show U.S. lead declines: Environmental Science and Technology, v. 31 , no. 9 , p. $424 \mathrm{~A}-428 \mathrm{~A}$.

Eisenreich, S.J., Capel, P.D., Robbins, J.A., and Boubonniere, R.A., 1989, Accumulation and diagenesis of chlorinated hydrocarbons in lacustrine sediments: Environmental Science and Technology, v. 23, no. 9 , p. $1,116-1,126$.

Foreman, W.T., Connor, B.G., Furlong, E.T., Vaught, D.G., and Merten, L.M., 1995, Methods of analysis by the U.S. Geological Survey National Water Quality Laboratory-Determination of organochlorine pesticides and polychlorinated biphenyls in bottom sediment by dual capillary-column gas chromatography with electron-capture detection: U.S. Geological Survey Open-File Report 94-140, 78 p.

International Boundary and Water Commission, 1988, Flow of the Rio Grande and related data: Water Bulletin no. 58, 144 p.

MacDonald, D.D., Ingersol, C.G., and Berger, T.A., 2000, Development and evaluation of consensus-based sediment quality guidelines for freshwater ecosystems: Archives of Environmental Contamination and Toxicology, v. 39, p. 20-31.

Van Metre, P.C., Callender, Edward, and Fuller, C.C., 1997, Historical trends in organochlorine compounds in river basins identified using sediment cores from reservoirs: Environmental Science and Technology, v. 31, no. 8, p. 2,339-2,344.

Van Metre, P.C., Mahler, B.J., and Furlong, E.T., 2000, Urban sprawl leaves its PAH signature: Environmental Science and Technology, v. 34 , no. 19 , p. 4,064-4,070.

Van Metre, P.C., Wilson, J.T., Callender, Edward, and Fuller, C.C., 1998, Similar rates of decrease of persistent, hydrophobic and particlereactive contaminants in riverine systems: Environmental Science and Technology, v. 32, no. 21, p. 3,312-3,317.

- B.J. Mahler and P.C. Van Metre

Any use of trade, product, or firm names is for descriptive purposes only and does not imply endorsement by the U.S. Government.

Information on technical reports and hydrologic data related to this study can be obtained from:

District Chief

U.S. Geological Survey

8027 Exchange Dr.

Austin, TX 78754-4733

E-mail: dc_tx@usgs.gov
Phone: (512) 927-3500

FAX: (512) 927-3590

World Wide Web:

http://tx.usgs.gov/ 